\title{
EXPLORAÇÃO SEXUAL JUVENIL NAS ÁGUAS AMAZÔNICAS E SUAS INTERFACES COM A ESCOLA
}

\section{YOUTH SEXUAL EXPLOITATION IN AMAZONIAN WATERS AND ITS INTERFACES WITH SCHOOL}

\author{
Ivany Pinto ${ }^{1}$ \\ Universidade Federal do Pará - UFPA \\ Andréa Vieira ${ }^{2}$ \\ Universidade Federal do Pará - UFPA
}

\section{Resumo}

Este texto intitulado "Exploração sexual juvenil nas águas amazônicas e suas interfaces com a escola" assinala os resultados do estudo de mestrado em Educação da Universidade Federal do Pará. Objetiva discutir as representações sociais de jovens alunos sobre exploração sexual nas balsas que transitam no arquipélago do Marajó, no Estado do Pará e o processo de escolarização vivido nesse contexto. Fundamenta-se na Teoria das Representações Sociais - TRS (MOSCOVICI, 2010; NASCIMENTO, 2002). São vistas no presente artigo as representações sociais (RS) constituídas pelos sujeitos da pesquisa e as implicações no processo de escolarização. Esses elementos e as análises teóricas apontaram que a exploração sexual nos rios e furos da paisagem amazônica é pouco visível e não possui a necessária problematização em muitos setores da sociedade. As ações do poder público não dão lugar para esse fenômeno em seu combate e enfrentamento. As medidas ao enfrentamento da exploração sexual presente nas águas amazônicas relacionam-se à implantação de programas de qualidade além da valorização desse universo escolar e sua comunidade, experiências positivas e potencializadores desses jovens alunos.

Palavras-chave: Exploração sexual juvenil; Representações Sociais; Educação.

\footnotetext{
${ }^{1}$ Possui graduação em Licenciatura em Psicologia pela Universidade da Amazônia (1984), graduação em Formação de Psicólogo pela Universidade da Amazônia (1985), graduação em Licenciatura em Letras pela Universidade Federal do Pará (1978), mestrado (1998) e doutorado (2002 em Psicologia da Educação pela Pontifícia Universidade Católica de São Paulo). Pós Doutorado (2011) pela Universidade Estadual do Rio de Janeiro. Atualmente é consultoria ad hocCoordenação de Aperfeiçoamento de Pessoal de Nível Superior -CAPES e do INEP - Professora Associado III da Universidade Federal do Pará.

${ }^{2}$ Doutoranda pelo Programa de pós-graduação da Universidade Federal do Pará (UFPA).
} 


\section{Abstract}

This text titled "Youth Sexual Exploitation in the Amazonian Waters and their Interfaces with the School" marks the results of the Master of Education study at the Federal University of Pará. It aims to discuss the social representations of young students about sexual exploitation in the ferries that transit the archipelago of Marajó, in the state of Pará, and the process of schooling lived in this context. It is based on the Theory of Social Representations - TRS (MOSCOVICI, 2010; NASCIMENTO, 2002). The social representations (RS) constituted by the research subjects and their implications in the schooling process are seen in this article. These elements and the theoretical analyzes pointed out that sexual exploitation in the rivers and narrow channels of the Amazonian landscape is not very visible and does not have the necessary problematization in many sectors of society. The actions of the public power do not give place to combat and confrontation with this phenomenon. Measures to combat sexual exploitation in Amazonian waters are related to the implementation of quality programs in addition to the appreciation of this school universe and its community, positive and empowering experiences of these young students.

Key words: Youth sexual exploitation; Social Representations; Education.

\section{INTRODUÇÃO}

Este estudo foi realizado por meio de pesquisa de mestrado em Educação pela Universidade Federal do Pará e versa sobre o fenômeno da exploração sexual juvenil e sua interface com a vida escolar dos jovens-alunos de uma escola ribeirinha no município de Breves, Pará.

Propor uma investigação nessa direção é uma forma de provocar a fala de jovens estudantes, cujo contingente a cada dia é silenciado e neutralizado em ações de exploração sexual a que são expostos e ameaçados nos rios que cruzam a llha do Marajó.

A situação de exploração sexual nas águas dos rios marajoaras e nas embarcações que circulam em demasia nesta região divide espaço de experiências e aprendizagens juntamente com a escola na vida de jovens.

Segundo Diógenes (2008) e Silva et al (1997), essa divisão é também determinada pela sobrevivência deste (a) jovem e de sua família. Isto faz com que, na maioria das vezes, ele (a) abandone a escola ou reprove no ano letivo.

Significa que, dentre outras variáveis que interferem na vida escolar do (a) aluno (a), a exploração sexual é uma delas. Contudo, as dificuldades encontram-se ainda centrados na capacidade cognitiva do aluno, como a reprovação e a desistência, como se outras - nelas, a exploração sexual - não tivessem visibilidade para compor elementos dessas dificuldades. 
Como narra Tupiassú (2005, p. 299), “é esta Amazônia da escassez que convive com o el dorado real, de fauna, flora, riqueza, cujas contas do inventário jamais se fecharam". Falamos, pois, do município de Breves, situado no maior arquipélago de todo planeta, a Ilha do Marajó, cuja juventude, como em qualquer outro lugar, possui desejos, comportamentos, vivências e aprendizados peculiares à sua história. Não somente da "Amazônia da escassez" expressa na citação acima, mas da Amazônia contraditória, da riqueza natural e da carência em políticas públicas que envolvem seu cotidiano como atuação principal.

Mais do que contraditória, a Amazônia Oriental, revela, em seus indicadores e fenômenos sociais, recorrência de violação de direitos humanos para ações mais responsáveis, como veremos mais adiante, mas que, por oposição, encanta os olhos de quem nunca a viu a entranha de intimidade e pertencimento de seus moradores.

A reportagem "As margens da Pobreza", do jornalista Marcelo Canelas, veiculada no Jornal Nacional de 20 de janeiro de 2005, ao abordar a situação das crianças e jovens marajoaras, particularmente sobre a situação de exploração sexual nos rios da Amazônia, ressalta que "um enorme rio de silêncio cobre a região de Breves".

É possível dizer que, dentre outros aspectos, o que se nota é a negligência das autoridades quanto à insuficiência de mecanismos de proteção e de direitos para o público infanto-juvenil ribeirinho, sua escolaridade a partir de sua formação socioeducativa e cidadã de qualidade no tempo presente.

Neste curso pela Ilha do Marajó, mítica barreira do mar, como rememora Loureiro (2001), formulamos sentidos que emergiram aos poucos na aproximação desta barragem chamada região do Marajó. Um lugar que vale tanto pelo seu investimento turístico quanto pelos direitos humanos, necessários para vivência da cidadania,

Não restam dúvidas de que o fenômeno da exploração sexual juvenil nas balsas do Marajó não seja uma ficção nas águas da Amazônia marajoara, algo que seja distante da nossa realidade e/ou desconhecido totalmente, uma vez que os veículos de comunicação assumem a responsabilidade de veicularem notícias sobre essa situação, ainda que muitas vezes em tom de tragédia.

Sua presença nos rios da Amazônia não é um fenômeno dos dias atuais. Como prática cruel e criminosa contra esse grupo, Silva et al (1997) assinala registros históricos que compilam estas práticas em espaços existentes nas margens dos rios e áreas de garimpagem com corpos infanto-juvenis explorados por pouco ou quase nada. 
Aproximamos nossos olhares norteados na seguinte indagação: Quais as Representações Sociais de jovens alunos de uma escola ribeirinha sobre a exploração sexual juvenil e quais as implicações nas suas vidas escolares? Articulamos ao campo educacional para constituir o estudo com questionamento na e da escola para construção de uma rede de proteção à juventude ribeirinha.

A escola, ao se encontrar inserida na comunidade também possui representatividade em seu discurso. É importante mediadora junto às famílias dos jovens da comunidade quanto à construção de medidas de enfrentamento à exploração sexual juvenil.

Para tanto, buscamos como objetivo mestre ${ }^{3}$ da pesquisa analisar as representações sociais de jovens alunos do Ensino Fundamental de uma escola ribeirinha no município de Breves, na faixa etária entre 15 e 20 anos, sobre exploração sexual nas balsas do Marajó e as implicações nas suas vidas escolares.

Embora existam diversas formas de analisar este fenômeno, conforme o objetivo do pesquisador, a sua metodologia de investigação e os campos de análise, a ênfase deste estudo é a análise do fenômeno da exploração sexual juvenil e interseções com a escola.

Apresentamos no primeiro momento os métodos e, a seguir, os procedimentos de coleta de informações e análise, para compreender e discutir a exploração sexual nas balsas que percorrem os rios marajoaras. No momento seguinte, os resultados e discussões sobre a temática, para analisarmos as representações sociais de alunos jovens sobre a exploração sexual nas balsas. Por fim, as considerações finais do trabalho.

\section{MÉTODO}

Nesta pesquisa, o referencial é o da pesquisa qualitativa e fundamenta-se na Teoria das Representações Sociais - TRS, com base em Moscovici (2010) e Nascimento (2002). A análise de dados se deu a partir dos referenciais metodológicos de Franco (2008) e Nascimento e Moraes (2010). A pesquisa desenvolvida com jovens matriculados em uma escola ribeirinha, na faixa etária entre 15 e 20 anos, do Ensino Fundamental da Educação Básica.

O estudo foi realizado com jovens de uma escola ribeirinha no município de Breves. Esse município integra a mesorregião de Marajó e a microrregião Furo de Breves,

\footnotetext{
${ }^{3} \mathrm{O}$ termo "mestre" refere-se ao objetivo geral.
} 
com uma população estimada de 101.096, de acordo com o Sistema de Informações de Indicadores Sociais do Estado do Pará - SIIS (2011) e tendo por limites geográficos os municípios de Afuá, Anajás, Melgaço, Bagre, Curralinho, São Sebastião da Boa Vista e Gurupá, todos pertencentes à Ilha do Marajó, segundo dados do Governo do Estado do Pará (2009).

Na primeira fase, realizamos o levantamento e organização do arcabouço teórico. $\mathrm{Na}$ segunda fase, realizamos o planejamento e a elaboração do estudo e da empiria elaboração da proposta de estudo a partir dos resultados parciais submetidos à análise da banca de qualificação deste estudo e ao Comitê de ética em pesquisa em seres humanos - CEP-UFPA (Anexo 1).

Posteriormente, a elaboração dos instrumentos para a empiria, sendo eles questionário e entrevista semiestruturada. Após essa etapa, a escolha dos sujeitos, considerando: interesse e disponibilidade; regularmente matriculados; d) jovens entre 15 e 20 anos, de ambos os sexos (DA SILVA e SOUZA E SILVA, 2005).

A quinta fase correspondeu ao tratamento dos conteúdos dos questionários e das entrevistas. Esses conteúdos são complementares entre si, uma vez que versaram sobre o mesmo tema e foram organizados pelas unidades de significado com base em seus contextos.

Franco (2008, p. 46) observa que as unidades de significado com base no contexto “podem ser consideradas como o 'pano de fundo' que imprime significado às unidades de análise". Implica em dizer que os sentidos inscritos nos conteúdos de uma fala articulamse nas malhas de textos e contextos plenos de sentidos.

Como afirma Nascimento,

Falar de escrita é falar de elaboração, construção, palavras, sentidos, imagens, enfim, movimento de imagens que se convertem em outras que repetem de forma diferente pela proximidade e distância de seus lugares e ainda pelo lugar de ordenação que ocupam nos elos de uma corrente de sentidos (2011, p. 25).

Realizamos a codificação e o registro dos questionários, o registro das entrevistas individuais e, posteriormente, a organização do conteúdo pelas unidades de significado e matrizes biográficas, com base em Franco (2008) e Pinto e Moraes (2010).

A seguir, o delineamento do tratamento e da análise das informações, composta pelas fases: $1^{\text {a }}$ - Registro das falas dos questionários e entrevistas; $2^{\underline{a}}$ - Organização do conteúdo das falas pelas temáticas de sentido e de contexto. Também a organização e a edição de painéis temáticos e contextuais, articuladas às informações da escola e da 
comunidade, por meio de painéis de imagens, que ilustraram o cotidiano, as paisagens, os lugares e as pessoas (NASCIMENTO, 2011, p. 26).

Nas fases seguintes estão: $3^{\underline{a}}$ - Elaboração de temáticas analíticas contextualizadas pelas unidades de significado. Momento também de elaboração das Matrizes Biográficas; 4a - Caracterização das imagens e sentidos das RS de jovens alunos de uma escola ribeirinha sobre exploração sexual juvenil e implicações nas suas

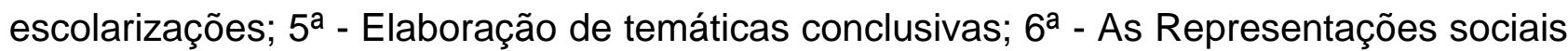
de jovens alunos de uma escola ribeirinha sobre exploração sexual juvenil e as implicações nas suas escolarizações.

As matrizes biográficas de jovens alunos (as) foram elaboradas a partir do conteúdo das entrevistas. Emprestamos os nomes fictícios de personagens do romance Marajó, do escritor Dalcídio Jurandir (2008), são eles: Rosália, Ormilda, Hilda, Alaide, Ramiro, Benedito. A escolha do termo matriz biográfica deu-se com 0 intuito de apresentar alguns traços biográficos dos jovens que participaram da entrevista, sobretudo aspectos referentes às suas trajetórias de vida, moradia, família, série escolar (SOUSA, 2008).

A organização dos discursos dos sujeitos deu-se a partir da organização das temáticas analíticas com base no contexto (FRANCO, 2008). Essa autora assinala que "o ponto de partida da Análise de Conteúdo é a mensagem, seja ela verbal (oral ou escrita), gestual, silenciosa, figurativa ou documental [...] expressa um significado e um sentido" (2008, p. 19).

Os conteúdos das falas dos (as) alunos (as) foram agrupados em categorias de análise, definidas em temáticas analíticas representativas.

Nas temáticas analíticas e representativas tomamos por referência as unidades de sentido e de contexto as quais agrupamos por semelhança e frequência. Ressaltamos que os conteúdos presentes nos instrumentos de coleta de informações serviram de base e articula-se entre si uma vez que tais conteúdos fazem parte do contexto classificado em temáticas analíticas. São elas: rio de possiblidades, rio que encanta, rio que desencanta, rio que traga.

Adotamos a abordagem teórica das Representações Sociais a partir de dois processos, o da objetivação e o da ancoragem, fundamentais na formação de uma representação social e compreensão dos significados atribuídos por esses jovens alunos.

Segundo Sá (1996, p. 47), na perspectiva "moscoviciana”, a objetivação "consiste em uma operação imaginante e estruturante, pela qual se dá uma forma - ou figura - 
específica ao conhecimento acerca do objeto, tornado concreto, quase tangível, o conceito abstrato, como que materializando a palavra". Significa dar forma para um objeto e/ou acontecimento tornando-o familiar aos esquemas cognitivos que o sujeito já possui.

A ancoragem é um processo que atribui uma classificação ou mesmo, denominação a esta imagem (MOSCOVICI, 2010). A ancoragem "é a atribuição pela sociedade de uma escala de valores e preferências para um objeto social em função das interações sociais".

Este processo "delimita o campo de uma representação, pelo recorte de uma rede de significações que dá corpo à representação, e permite que esta delimitação seja compatível com os valores sociais existentes" (NASCIMENTO, 2002).

Vale acrescentar que tanto a objetivação e quanto a ancoragem são processos interligados que orientam pensamentos, sentimentos e ações consensuais de grupos sociais. Daí a importância dos estudos das Representações Sociais na vida destes grupos.

A aproximação conclusiva deste estudo não se traduz em fechamento do ciclo, mas indagações novas. Como acrescenta Nascimento (2011) sobre a construção de uma pesquisa, sempre faltam respostas, brechas a serem preenchidas.

\section{RESULTADOS}

Notamos nos resultados do estudo que as pesquisas sobre exploração sexual juvenil são recentes. Apesar da abrangência e diversidade do tema, percebe-se um espaço de estudo ainda aberto, especialmente sobre a realidade amazônica.

Sônia Sousa afirma que, segundo sua denominação, a prostituição infanto-juvenil PIJ divide-se em dois momentos distintos, o primeiro: "na década de 1980, com a publicação de estudos e pesquisas que versam sobre o mundo da 'menina de rua', e o segundo, na década de 1990, em que a PIJ se caracterizará como um objeto de estudo distinto, com identidade própria" (2002, p. 11).

A promulgação do Ano Internacional da Criança, em 1979, é um marco referencial no que diz respeito à atenção de governos para problemas infanto-juvenis em diversas partes do mundo, com repercussões inclusive no Brasil (SOUSA, 2002; LANDINI, 2005, MELLO 2010, TEIXEIRA, 2001). Segundo Sousa (2002), esse período demarcou o início de discussões referentes à população infanto-juvenil feminina brasileira, cuja primeira denominação foi "meninas de rua". 
A pesquisa desenvolvida por Saffioti (1989 apud Sousa, 2002) na ampliação do conceito para além da dimensão econômica e acrescenta a dimensão de relação de poder, na qual a exploração sexual se configura também como uma forma de obter vantagens por parte do explorador.

Mello (2010) destaca o Movimento Nacional de Meninos e Meninas de Rua MNMMR, em 1985, a promulgação da Constituição Federal, em 1988 e o Estatuto da Criança e Adolescente - ECA, Lei № 8.069, de 13 de julho de 1990, como parâmetros para crianças e adolescentes serem vistos como sujeitos de direitos. O estabelecimento no ECA da faixa etária crianças e adolescentes foi muito relevante nesse período para estabelecer os aspectos da exploração sexual.

Estes jovens, em sua maioria, são inseridos por questões como as desigualdades sociais, o gênero, a precariedade na efetivação da cidadania para jovens e pouca relevância dada à capacidade juvenil na superação e formação de escolhas (TAQUETTE, 2007).

A Declaração de Estocolmo (1999), resultado do Congresso Mundial sobre Exploração Sexual de Crianças e Adolescentes realizado no ano de 1998, orienta a definição da exploração sexual como uma das piores formas de trabalho:

A exploração Sexual Comercial de Crianças é uma violação fundamental dos seus direitos. Constitui-se em uma forma de coerção e violência contra as crianças, que pode implicar em trabalho forçado e formas contemporâneas de escravidão (1999, p. 1).

Essa Declaração de Estocolmo aponta também alguns fatores que contribuem para a exploração sexual. De acordo com esta Declaração, resultado do Congresso Mundial sobre a Exploração Sexual de Crianças e Adolescentes, realizada em Estocolmo, em 1998:

São vários os fatores que contribuem para a exploração sexual comercial de crianças, dentre os mais complexos temos as disparidades econômicas; as estruturas socioeconômicas injustas; a desintegração familiar; a questão da educação, consumismo; a migração rural-urbana; a discriminação de gênero; a conduta sexual masculina irresponsável; as práticas tradicionais nocivas e o tráfico de crianças. Portanto, a pobreza não pode ser considerada como o único fator determinante do fenômeno. Todos esses fatores aumentam a vulnerabilidade de meninas e meninos, frente àqueles que buscam utilizá-los para fins de exploração sexual comercial (1998, p. 1).

No campo da pesquisa, autores afirmam que a impunidade, a ausência de políticas sociais e os apelos sexuais que movem a sociedade moderna são considerados os principais fatores que estimulam mais esse problema que se confunde como um 
comportamento cultural pouco aprofundado pelas pesquisas (LIBÓRIO, 2005; CÉSAR \& LEAL, 1998; TAQUETE, 2007).

Os sujeitos envolvidos na rede de exploração vivenciam privação social e cultural e podem perder os vínculos com a escola. As crianças envolvidas em rede de exploração em muitos casos estão sujeitas a diversas violações e são pertencentes a grupos sociais detentores de menor poder social, político e econômico, "inter-relacionadas à violência estrutural" (LIBÓRIO, 2005).

Leal (2003) define o fenômeno social da exploração sexual como:

Uma relação de mercantilização (exploração/dominação) e abuso (poder) do corpo de crianças e adolescentes (oferta) por exploradores sexuais (mercadores), organizados em redes de comercialização local e global (mercado), ou por pais, ou responsáveis, e por consumidores de serviços sexuais pagos (demanda) (2003, p. 1).

Como assevera Taquete (2007), a exploração sexual gera implicações no desenvolvimento dos sujeitos inseridos na exploração. Pare ela, significa, sobretudo, "uma ameaça à sua integridade física e psicossocial. Constitui uma violação fundamental do direito humano e do direito ao desenvolvimento de uma sexualidade saudável" (2007, p. 162).

A prostituição, como uma das formas de exploração sexual, assume ao longo das culturas modernas diversas características. Ainda que não seja nosso foco de investigação, cabe observar que a prostituição tem suas raízes no desenvolvimento histórico do patriarcado (BOTELHO, 2003; AZEVEDO e GUERRA, 2007).

Conduzidos pelas questões definidas por Jodelet (2001) e apreendidas a partir das informações partilhadas pelos interlocutores de nosso estudo a fim de constituir suas representações sociais sobre o fenômeno da exploração sexual juvenil, quais sejam: sobre o que sabe e com que efeito?

São questionamentos que traçaram a linha de análise do estudo em tela para identificar e analisar a produção de tais representações sociais, estabelecendo conexões entre o universo escolar.

Assim, neste movimento juntamos "como quem junta pequenas peças de sentido num sentido mais amplo; [...] percorrendo-os sem, contudo, neles se esgotar, aberta ao que se passa mesmo ao que se passa quando nada se passa" (PAIS, 2002, p. 31).

Verificamos o rio como cenário de aprendizados e partilhas, em que se tecem as temáticas que revelam os matizes de suas águas; as imagens e respectivos significados que organizam as objetivações; e as ancoragens que edificam as representações sociais 
de jovens sobre o rio. Tais matizes são representados pelos cenários de vivências e desejos desses jovens.

A paisagem social ribeirinha ora narrada é um retrato de uma realidade que "se insinua, não se entrega [...] ela tem que ser imaginada, descoberta, construída", como assinala Pais (2002, p. 29-30). Esses dizeres foram tecidos não somente por palavras, mas revelados nos seus silêncios, nos seus "senões", nas concordâncias e adesões, bem como nas capturas em nossas andanças pelo rio Buiussú, consoantes a uma história em muitos casos silenciada.

O rio foi nossa referência, considerando-o não apenas onde circulam mercadorias e transitam moradores, mas também como espaço de lazer, de consumo e de socialização da população. Esse rio, muitas vezes, marca uma ocasião propícia para relacionamentos com pessoas que podem se utilizar da vulnerabilidade dessa população, da limitação ou de quase nenhum mecanismo de controle legal na.

O mesmo rio que funciona praticamente como a rua da comunidade para que a população possa suprir suas necessidades nas outras comunidades e cidades circunvizinhas (como Melgaço, Portel, Bagre) é também o rio que funciona como caminho para que jovens cheguem a pontos onde trafegam embarcações para serem conduzidas à exploração sexual.

Neste rio também está presente a escola como um lugar de grande importância para os jovens alunos. Espaço este onde, além do aprendizado do conhecimento sistematizado se faz presente também os vínculos de amizade que se misturam às práticas educativas e aos aprendizados escolares como um conjunto de proposições para formação do jovem para a vida. Além disso, o rio também é espaço e ponto de referência onde estabelecem as representações sobre o fenômeno da exploração sexual. Vejamos:

O rio de possibilidades: Esta representação social se vincula à relação dos alunos com o rio. Registra não somente a paisagem, mas também elementos que contornam os modos de vida, aprendizados e partilhas desses jovens. Essa relação forma-se na história, na geografia e na cultura de seus sujeitos, como pilares sobre os quais sustentam suas relações e constituem do ponto de vista material e simbólico, sua produção cultural (TAVARES e TRINDADE JUNIOR, 2008).

A imagem do rio de possibilidades agrupa os sentidos das falas dos (as) jovens alunos (as) por meio dos contornos que suas vivências se organizam e se estabelecem. Isto é, são variadas as formas como os jovens se veem nesse universo, seja como universo ora de diversão, ora de trabalho, de encontro, de perigo, entre outros, que 
marcam seu olhar sobre esse lugar, o rio que determina a vida de todos. Vale dizer que o rio não possui uma significação fixa, ao contrário, é móvel e mutável.

Podemos notar nas falas dos (as) jovens alunos (as) que as possibilidades de aprender estão inscritas em processos de práticas diárias, não somente na escola, mas que se formam também nas descobertas diante da geografia e sociabilidade na comunidade onde moram.

Os jovens reconhecem a paisagem ribeirinha enquanto espaço para aprendizagem e sociabilidade. As informações dos jovens também chamam atenção para o fato de enveredarem-se para as possibilidades de perigo que determinadas experiências proporcionam.

O rio que encanta: Esta representação social se vincula à imagem do rio que encanta e reúne significações construídas e consensuadas pelos (as) jovens em seus diálogos com o vivido a partir do encantamento que este produz. Não se trata de experiências do encantar mitológico, mas de desejos imaginados projetados e sua existência concreta tecida em seu dia-a-dia.

O encantamento diante do movimento intenso de embarcações que ocorre na frente do rio Buiussú é atribuído pelos jovens, especialmente nos horários em que estão na escola. Nela, a admiração é uma constante.

O rio que desencanta: A terceira representação social se vincula à imagem do rio que desencanta e reúne sentidos sobre as manifestações dos (as) alunos (as) diante da exploração sexual juvenil.

O caminhar pelo rio é uma atividade de socialização e diversão frequentemente mencionada pelos jovens alunos, além de se constituir em uma atividade de comércio, de compra e venda de mercadoria, para aqueles que contribuem com a renda familiar e/ou fazem alguns serviços como de compra de alguns produtos.

Essa rua, que é o rio, é vista por estes jovens como violenta e perigosa, uma vez que segundo eles é onde ocorre a exploração sexual de muitas jovens.

A maioria dos jovens entrevistados descreve a atividade de ir às balsas para compra ou venda de algum produto como uma situação que deixa tanto crianças quanto jovens vulneráveis à violência sexual. Dentre as formas identificadas pelos estudantes, a exploração sexual é vista como uma forma de obter meios para seu sustento, por exemplo: pequenas quantias de dinheiro, roupas, combustível (em especial o óleo diesel), sobras de alimento, entre outros. 
Os avanços referentes ao enfrentamento à exploração sexual infanto-juvenil com a conquista das leis, mecanismos de proteção e concepções sobre a infância e adolescência ainda não conseguiram alcançar os (as) jovens imersos nessa realidade ou prestes a vivê-la.

Isto nos faz pensar a forma como a família, mas também as próprias jovens entendem a situação. Elas se inserem em uma relação de troca aos ditames do capitalismo como se elas, as jovens, fosse uma mercadoria (LIBÓRIO, 2005).

Por esta lógica, a da objetivação do corpo como mercadoria, existe por parte das famílias e das jovens a dificuldade de reconhecer que se trata de uma exploração, uma vez que, além de não haver a avaliação do valor do capital adquirido com essa troca, não há a problematizarão e diferenciação entre sujeito e mercadoria. $O$ valor da vida na perspectiva da sua manutenção parece subverter outros valores que dignificam a condição humana (DIÓGENES, 2008).

Como destaca Botelho (2002, p. 71), estas famílias não se originam no vazio. Elas se inscrevem nesse contexto "articuladas à história social e econômica do lugar e da época em que vivem". O que nos faz pensar que as famílias (da comunidade em estudo) possuem uma convivência desafiadora, pois é quase invisível a presença do poder público na mesma proporção da presença das políticas preventivas e de erradicação da exploração sexual juvenil, como: a assistência social, de saúde, educacional, dentre outras necessárias para o desenvolvimento da população e suprimento das necessidades materiais, além daquelas formativas e profissionais para os jovens e demais sujeitos da comunidade como alternativas de trabalho.

Uma das atividades consideradas como uma forma de garantia da sobrevivência da (o) jovem e da sua família é exploração sexual. Esta possui o seu paradoxo no consentimento pelo menos aparente da maioria das jovens que "atracam nas balsas".

Segundo estes (as) alunos (as), na primeira vez o medo foi maior e a resistência também, mas com a continuação o medo dá lugar à coragem e à certeza de que desceria da balsa com algum alimento e algum dinheiro para levar para casa.

O diálogo que conseguimos estabelecer com estes jovens/alunos sobre a vulnerabilidade que os assediam a todo instante não foi tarefa fácil. A representação social pactuada pelo grupo se ancora sobre o silêncio que consideramos como o não-dito. Este pode ser lido de diversas formas por nós: a) objetivação do corpo; b) constrangimento; c) medo de sofrer preconceito e também receber a designação de "balseira". 
O rio que traga: Esta representação social se articula a imagem do rio que traga. Reúne sentidos sobre as manifestações dos (as) alunos (as) diante da exploração sexual juvenil, particularmente a respeito da forma como estes jovens percebem esta situação.

Vejamos o depoimento abaixo:

Fazer negócio de besteira... é isso que eles querem porque aqui no Buiussú já fizeram... se não fosse uma mulher falar que era parente dela aí eles chamaram o barco aí o homem que tava com a menina... ia levar a menina... aí ele perguntou se era parente da mulher aí ela falou que sim mas só que não era nadinha pra mulher aí eles mandaram soltar ela... eles pegaram e iam embora.

(Alaíde, quatorze anos, Rio Preguição.

De acordo com Alaíde, há pouca intimidação na abordagem para exploração sexual. Embora o amparo legal assegure os direitos de proteção integral aos jovens, um conteúdo legítimo enquanto sujeitos de direitos, as práticas vivenciadas por esses jovens assinalam a inexistência de correspondência dessa garantia.

Os jovens aprendem precocemente as circunstâncias dessa vulnerabilidade, isto é, que estão vulneráveis às tentativas de exploração sexual de crianças e adolescentes. "Fazer negócio de besteira" foi termo usado pela jovem para caracterizar como ocorre essa situação.

Segundo Hazeu (2004, p. 44-45), a exploração sexual de jovens é considerada uma "troca de favores sexuais com um ou mais clientes por bens materiais e/ou sociais, na qual se estabelece um contato direto entre o consumidor e a/o prostituída/o". A literatura sobre esse tema assinala ainda que, em se tratando de crianças e adolescentes, a exploração sexual se traduz enquanto violação aos direitos fundamentais da criança e do adolescente.

À luz de mecanismos legais de proteção aos direitos de crianças e adolescentes, como por exemplo, a Lei $n .^{\circ} 8.069$, de 13 de Julho de 1990, que dispõe sobre o Estatuto da Criança e Adolescente - ECA, o envolvimento de crianças e adolescentes em rede de exploração sexual como aqui compreendemos ser a exploração nas balsas, é uma violação aos direitos à liberdade, ao respeito e à dignidade desses sujeitos. Inclusive se considerarmos a faixa etária desses sujeitos, que pelo que dispõe tal Lei, tem assegurados esta proteção e inviolabilidade da integridade física, psíquica e moral.

A lei estabelece, nitidamente, os direitos de crianças e adolescentes. Entretanto, a realidade de muitas crianças e jovens ainda é distante do que rege o discurso jurídicolegal. Certamente o problema é imensamente complexo e não pode ser visto somente pelo aspecto legal, mas entendemos que, em se tratando da garantia de uniformidade de 
direitos, não podemos nos furtar de ver a problemática da exploração sexual contra jovens também como um descaso absoluto aos direitos desses sujeitos.

Tais direitos devem ser extensivos a todas as crianças e jovens, seja qual for sua etnia, classe social, sexo e local de moradia. As ações que atentam contra esses direitos, especialmente por parte do explorador ou abusador, comprometem imensamente a autoestima e sua autonomia afetiva.

Azevedo e Guerra (2007, p. 78) frisam que "o adulto desenvolve na criança [e na jovem] sentimentos que impedem ou, no mínimo, dificultam uma atitude de desafio, caminhando na direção da denúncia do agressor".

As denúncias sobre a exploração sexual de crianças e jovens nas regiões ribeirinhas ganharam visibilidade nos noticiários e reportagens jornalísticas, a partir das denúncias feitas pelas entidades religiosas e organizações sociais da área dos direitos humanos.

Ainda no ano de 2005, denúncias feitas pelo bispo Dom Luiz Azcona, da Prelazia do Marajó à CPI da Pedofilia da Câmara dos Deputados (2010), revelavam a presença da exploração sexual nas balsas que circulam nas vias fluviais da região marajoara.

Esta denúncia desencadeou uma série de reportagens sobre este problema. A instalação da CPI da Pedofilia na Assembleia Legislativa do Pará foi uma das medidas que acentuaram as condições precárias da infância e adolescência não somente no local, mas em todo o Estado.

Torna visível que a problemática da exploração sexual não é naturalizada no contexto do Marajó, como percebemos nos relatos dos (as) jovens. O que é ocultado é o direito à proteção integral de crianças e jovens assim como a morosidade em garantir a inserção desses sujeitos no contexto de mudanças históricas de paradigmas em relação aos direitos infanto-juvenis.

A ausência do poder público é um dos problemas mais graves. Os relatos dos (as) jovens evidenciam que suas experiências escolares são entrecortadas pela necessidade de buscar alternativas para superação dos problemas impostos pelo cotidiano, sobretudo as dificuldades materiais impressas no dia-a-dia.

Podemos notar que, na percepção dos (as) jovens, a exploração sexual relacionase às condições de vida, que se operam sobretudo pelas condições socioeconômicas que vivenciam.

Hazeu (2004) assinala que a privação econômica e social pode ser considerada um dos aspectos mais expressivos que condicionam os grupos juvenis vulneráveis à 
exploração sexual. Segundo este autor, "a falta de oportunidades de emprego, a má distribuição nas funções disponíveis, principalmente para mulheres e para pessoas com baixa escolaridade, também fazem do mercado do sexo uma alternativa atrativa" (HAZEU, 2004, p. 51).

Esse contexto não deve ser visto como situações isoladas e individuais dessas famílias, "mas como parte da história social da exploração" (AZEVEDO e GUERRA, 2007, p. 28-29).

Isto porque as famílias estão imersas em um modelo civilizatório que as populações da Amazônia vivenciaram e que ainda vivenciam cuja expropriação da biodiversidade (aspectos físicos) e sociodiversidade (aspectos humanos) aprofundam desigualdades e problemas sociais instalados em ciclos econômicos anteriores e persistentes em nossa história contemporânea (ARAÚJO, 2009).

Além disso, nota-se também que a culpabilidade da exploração sexual recai sobre a jovem como uma condição de "escolha" frente à falta de condições materiais de sobrevivência. Contrário a essa perspectiva, muitos jovens alunos expuseram a indignação quanto à violência sexual e comercialização infanto-juvenil como algo que compõe o rol de suas preocupações.

A presença da exploração sexual deixa evidente que os direitos dessas crianças e jovens são desrespeitados em níveis extremos, uma vez que, além das restrições materiais e limitações de meios de subsistência, completa-se tal violação por meio da violência sexual, como aqui vemos que se tipificam tais crimes.

O "medo" de ser balseira é presente nos discursos dos (as) jovens, sobretudo do sexo feminino. Os jovens expressaram vergonha de ver, medo de ser, de "ficar falada na boca do povo".

Cumpre notar que a denominação balseira, como forma para denominar jovens que estão inseridas na exploração sexual, merece maior problematização na região do município de Breves. Nisso está a precocidade do envolvimento de meninas e jovens na exploração sexual.

Entretanto, as jovens não deixam de ser classificadas como tal. Portanto, uma simbologia carregada de sentidos, impressa por meio de um olhar fragmentado e que reduz outras possibilidades de ser dessa jovem. Além disso, esta designação separa a jovem do contexto que destacamos acima como impulsionador ou facilitador para inserção na exploração sexual. 
Outro aspecto é o sentimento de culpa. Alguns jovens diziam que a "balsa acaba com a menina", o que nos faz notar que os jovens direcionam para si a sua desestruturação pela sua inserção na exploração. Significa dizer que:

O aniquilamento da autoestima, o sentimento de que ela só pode ser amada, ou pelo menos notada, se obedecer às ordens do adulto, a cumplicidade que foi obrigada a desenvolver tornam a criança prostituível. Isto é, o adulto desenvolve na criança sentimentos que impedem ou, no mínimo, dificultam uma atitude de desafio, caminhando na direção da denúncia do agressor. A criança é, pois, física e emocionalmente indefesa. Sua dependência, nos dois campos, em relação ao adulto, torna-a presa fácil das ambições, de vários gêneros, do agressor (AZEVEDO $E$ GUERRA, 2007, p. 78).

Prevalece uma relação desigual, de estigmas que ainda hoje, já com 22 anos, ainda faz parte de sua história na comunidade. A exploração sexual ocupa um grande peso na sua vivência, descaracteriza a sua condição de sujeito, de sujeito de direitos.

\section{DISCUSSÃO}

A reflexão e a discussão acerca das representações sociais sobre a exploração sexual remetem a um processo representativo, que é ao mesmo tempo individual e coletivo. As imagens e os sentidos que jovens alunos configuram sobre a exploração sexual nos forneceram pistas para que pudéssemos inferir sobre as objetivações e as ancoragens que constituem as Representações Sociais que estes jovens partilham sobre a exploração sexual juvenil nas balsas do Marajó.

Dentre as formas de abordagem do objeto de estudo que a Teoria das Representações Sociais sugere, elegemos a abordagem pelos dois processos que a compõe. Entendemos que este é um caminho que possibilita a compreensão das articulações e negociações consensuadas por meio da linguagem que orientam os pensamentos, os afetos, os fazeres deste grupo juvenil. Além de que, para quem inicia como nós estudos neste campo, acreditamos que esta opção se coloca como a viável aqui nesta trajetória.

As imagens das objetivações e das ancoragens que articulam sentidos partilhados pelo grupo de jovens-alunos sobre a exploração sexual orientam ações e interações destes jovens com o contexto em que vivem.

As objetivações e as ancoragens de jovens sobre a exploração sexual se compõem entre o rio de possibilidades e o rio que traga. Enquanto rio de possibilidades, de um lado, existe o encantamento que nos parece ser o sentido mais forte, valoroso e promissor 
ancorado nesta imagem. A soberania natural do rio se impõe à paisagem às limitações. De outro, destaca-se nestas RS a imagem do rio que traga. A vinculação de sentido em destaque com esta imagem é o desencanto. Tal imagem emerge das experiências e vivências relacionadas à exploração sexual e de perceberem os mecanismos que estruturam tal situação segundo o contexto da comunidade.

A objetivação da imagem do rio que traga está vinculada ao significado do desencanto. Possivelmente este sentido ancorado na objetivação da imagem do rio que traga partilha o pensamento destes jovens ao saberem da ameaça de serem absorvidos por este mesmo rio que encanta e que traz possibilidades para eles. Isto indica que os jovens da comunidade se encontram vulneráveis, pois a qualquer momento podem ceder ao apelo da violência e da exploração sexual e cair no rio que traga.

Vale acrescentar que as Representações Sociais de jovens sobre a exploração sexual não tiveram seu início para algumas das jovens deste estudo com o atracar nas balsas. Os elos iniciais desta corrente de sentidos partilhados por alguns grupos de jovens deste contexto iniciaram no meio familiar com figuras parentais e ou próximas. $\mathrm{O}$ desinteresse e a saída da escola são decorrentes do desencanto e do processo de ser aos poucos tragada pelo rio.

A imagem mental objetivada no sentimento de culpa que os (as) jovens alunos (as) carregam sobre e/ou pela exploração sexual inferir os seguintes significados: do julgamento da comunidade, pela atribuição do nome "balseira", de sofrer ameaças de quem a explorou; perder sua fonte de renda e também pela ausência do poder público para coibir a situação da exploração sexual juvenil.

O ponto de ancoragem que se destaca conjuntamente com o sentimento de culpa é o silêncio que podemos denominar o sentimento da palavra sem verbo porque não têm ação. O silêncio reverbera a ausência de ação do poder público, ausência de ação conjunta dos jovens, comunidade, escola, ausência do sujeito.

O silêncio possivelmente se inscreve no medo, na objetificação, no esvaziamento da problematização da condição e materialização de sua existência.

No que se refere às implicações escolares a partir das representações sociais de jovens alunos sobre a exploração sexual juvenil nas balsas do Marajó, apontamos as dimensões: 1) Fragilização no processo psicossocial de desenvolvimento dos jovens; 2) Falta de aprendizagem; 3) Desatenção nos conteúdos e atividades escolares; 4) Desinteresse pela escolarização (Abandono escolar e Repetência escolar). 
No estudo apontamos a escola como ponto de defeso permanente na rede de proteção e enfrentamento à exploração sexual juvenil. Essa escola se inscreve em um grande desafio, o de promover cidadania. Isto, porém, não pode ser visto de maneira acrítica e deslocada da realidade em que está inserida, na medida em que as condições de sobrevivência da população se articulam de forma mais ampla a estas e a outras mazelas sociais.

Isso anuncia a necessidade de um defeso para além da escola e que garanta a construção e a permanência de uma rede de sobrevivência digna para as pessoas da comunidade, sobretudo crianças e jovens. Que aliado aos outros graves problemas que as escolas enfrentam, a promoção da cidadania é fundamental (SOUZA, 2009).

Os membros da escola também anseiam pela construção de estratégias de enfrentamento da exploração sexual, a fim de auxiliar os jovens nessa superação. As ações na comunidade escolar ainda são pontuais e não possuem um projeto que auxilie não somente a jovem, mas também os professores, os funcionários da escola e a família no seu desenvolvimento psicossocial e na vida escolar desses jovens.

A escola coloca-se, então, no desafio e no compromisso ético e legal de espaço também de notificação de suspeitas de maus-tratos, pelos quais a exploração sexual se inclui. É certo que não pode assumir este papel isoladamente, contudo, cabe reconhecêla como essencial na articulação destas políticas, tanto de atendimento como de prevenção.

A escola, que compõe os organismos do sistema de garantia dos direitos de crianças e adolescentes, pode fortalecer sua atuação adotando seu atendimento dentro do paradigma de redes - com ações que não sejam temporárias -, de projetos isolados e pontuais - mas permanentes e integrais.

Em nossas visitas à comunidade, percebemos que as jovens que estão inseridas na exploração sexual são de famílias que vivenciam diversas privações e, mesmo que tenham abandonado a escola, estiveram no sistema público de ensino.

No enfrentamento da violência e da exploração sexual juvenil, um dos primeiros passos é a escola ver-se enquanto lugar de defeso e integrar-se como um dos lugares importantes no Sistema de Garantia de Direitos, de proteção, de escuta, além de denúncia diante dos pedidos de ajuda, compreendidos em uma postura de compromisso, respeito, acolhida e busca de justiça. 


\section{CONSIDERAÇÕES FINAIS}

Ao chegarmos ao final desta reflexão apresentada no presente artigo, retomamos os objetivos que orientaram esta caminhada para repensá-los, agora, porém, à guisa de sua conclusão. O curso desta expedição teve como objetivo mestre a análise das representações sociais de jovens-alunos do ensino fundamental de uma escola ribeirinha sobre exploração sexual e as implicações nas suas vidas escolares.

As representações sociais destes jovens sobre a exploração sexual juvenil foram tecidas a partir contexto ribeirinho no qual estes sujeitos vivem e compartilham suas experiências. Da mesma forma, o contexto escolar desempenhou um papel importante na condução deste estudo e apreensão de suas representações no que tange as implicações desse fenômeno em suas vidas escolares. Assim, suas Representações Sociais se entrelaçam na trama rio, escola e comunidade.

As Representações Sociais dos jovens transitam nas vivências e nos sentimentos destes sobre a exploração sexual juvenil. As significações partilhadas assinalam como imagem o sentimento de culpa, que se destaca dentro de significados de serem julgados pela comunidade: ter a atribuição de balseira, medo de sofrer ameaças, além do sentimento de ausência do poder público.

A partir destas significações, destaca-se enquanto ponto de ancoragem o silêncio. Este sentimento que não se pode ouvir brada de sentidos, ora pelo medo de sofrer alguma espécie de julgamento social ora pelo sentimento de esvaziamento que esta condição da exploração sexual se materializa em suas vivências.

A escola, bem como seus sujeitos, em particular seus alunos, convivem com situações de exploração sexual, manifestados com intensidade, implicando na desistência da escola como um obstáculo de sua ascensão e formação cidadã.

Em síntese, aspectos como a escuta e a ação estão nas bases para possibilitar a problematização necessária da exploração sexual juvenil, em particular nos espaços pelos quais este jovem transita, seja a escola, a família, a comunidade. Entretanto, estes sujeitos não deixam de dizer e/ou representar sobre a exploração sexual, uma vez que esse fenômeno perpassa pelos fios entrelaçados nas suas experiências e reflexões sobre si e sobre o outro (seja seu colega, seu professor, um membro comunidade, seja mesmo aquele sujeito visto como explorador). 
A exploração sexual nos rios e furos da paisagem amazônica ainda é pouco visível, uma vez que as ações do poder público ainda não dão o lugar para este fenômeno no sentido de seu combate e enfrentamento.

No que tange ao impacto da exploração sexual juvenil na vida dos jovens, apreendemos discursos que também assinalam um significativo sentimento de fragilidade de medidas protetivas de coibição desse fenômeno na região. O que acena uma lacuna do poder público no sentido de habilitar estes jovens a uma cidadania viva, que subverta as precárias condições a quais são submetidos.

A problemática da exploração sexual juvenil nas regiões ribeirinhas ainda possui grandes desafios de superação. Um deles é a necessidade de sua visibilidade, bem como ações mais eficazes que promovam uma cidadania digna a essa população, uma vez que as políticas públicas, fiscalização e acompanhamento da escola e da família ainda estão longe dessa população.

\section{REFERÊNCIAS}

ARAÚJO, Sônia Maria da Silva. A constituição do sujeito e a diversidade (ameaçada) da Amazônia. Revista Múltiplas Leituras, v.2, n. 1, p. 39-49, jan. / jun. 2009.

AZEVEDO, Maria Amélia. GUERRA, Viviane Nogueira. Crianças Vitimizadas: a síndrome do pequeno poder. $2^{\text {a }}$ ed., São Paulo: Iglu, 2007.

BELÉM (PA). Assembleia Legislativa do Estado do Pará. Relatório da CPI da Pedofilia da Assembleia Legislativa do Estado do Pará - Alepa sobre os crimes de pedofilia. Belém - PA, 2010.

BOTELHO, Stella Maris Nogueira. Prostituição de Adolescentes: uma imagem construída na diversidade da sociedade. Dissertação de Mestrado. Departamento Materno-infantil e saúde pública - Escola de Enfermagem de Ribeirão Preto/ USP. 2002.

CANELAS, Marcelo. As margens da Pobreza. Jornal Nacional. Rede Globo de Televisão, 202 de jan. 2005.2 Disponível em: http://jornalnacional.globo.com/Telejornais/JN/OMUL558360-10406,00AS+MARGENS+DA+POBREZA.html. Acesso em: 15 de fev. 2011. Ano 2005.

DA SILVA, Helena Oliveira; SOUZA E SILVA, Jailson. Análise da Violência contra a criança e o adolescente segundo o ciclo de vida no Brasil. São Paulo: Global: UNICEF, 2005.

DIÓGENES, G. (Org.) Os sete sentimentos capitais - Exploração sexual comercial de crianças e adolescentes. 2ª Edição. São Paulo. Anna-blume, 2008. 
FRANCO, Maria Laura Publisi Barbosa. Análise do conteúdo. Brasília, 3ª edição: Líber Livro Editora, 2008.

GOVERNO DO PARÁ. Estatística Municipal de Breves. Secretaria de Estado de Planejamento, Orçamento e Finanças - SEPOF, Governo do Estado do Pará, 2009.

HAZEU. Marcel. Direitos sexuais da criança e do adolescente - uma visão interdisciplinar para o enfrentamento da violência sexual contra criança e adolescente. Amazônia: TXAI. 2004.

JODELET, Denise. As representações sociais. Tradução Lilian Ulup. Rio de Janeiro: EdUERJ, 2001.

JURANDIR, Dalcídio. Marajó. 4.ed. - Belém: EDUFPA; Rio de Janeiro: Casa Rui Barbosa, 2008.

LANDINI, Tatiana Savoia. Horror, honra e direitos: violência sexual contra crianças no século XX. Tese de doutorado, Departamento de sociologia, FFLCH/USP, São Paulo, 2005. Disponível em http://www.teses.usp.br/teses/disponiveis/8/8132/tde-11012006194947/pt-br.php. Acesso em 06 ago. 2008.

LEAL, M. L. P. A Exploração Sexual comercial de meninos, meninas e adolescentes na América Latina e Caribe (Relatório Final-Brasil). Brasília: CECRIA, IIN, Ministério da Justiça, UNICEF, CESE, 1999.

LIBÓRIO, Renata Maria Coimbra. Adolescentes em situação de prostituição: uma análise sobre a exploração sexual comercial na sociedade contemporânea. Psicol. 2005, vol.18, n.3, pp. 413-420. ISSN 0102-7972. Do. 10.1590/S010279722005000300016.

LOUREIRO, João de Jesus Paes. João de Jesus Paes Loureiro: obras reunidas: poesia I. São Paulo: Escrituras editora, 2001.

MELLO, L. C. A. Exploração sexual comercial de crianças e adolescentes: o estado da arte nas produções acadêmicas em psicologia. Dissertação de mestrado. Universidade Federal do Rio Grande do Norte, Natal. 2010.

MINISTÉRIO PÚBLICO DO ESTADO DO PARÁ - MPPA. Sistema de Informações de Indicadores Sociais. Disponível em https://www2.mppa.mp.br/sistemas/gcsubsites/index.php?action=MenuOrgao.showMenu\& id=679\&oOrgao=53. Acesso em 15 jan 2011 .

MOSCOVICI, Serge. Representações sociais: investigações em psicologia social. 7. Ed. - Petrópolis, RJ: Vozes, 2010.

NASCIMENTO, Ivany Pinto. Escrituras, imagens e sentidos: saberes sobre o objeto de pesquisa na educação. Belém, PA: Editora Cromos, 2011.

MORAES, K. A. F. Para que serve a escola? As representações sociais de adolescentes grávidas. In: Dossiê Sexualidade e Gêneros: reflexões teóricas e empírica. PIMENTEL, Adelma et. al. Ed. Letras a margem, 2010. 
As representações socais dos projetos de vida dos adolescentes: um estudo psicossocial. São Paulo: PUC. 2002.

PAIS, José Machado. Sociologia da vida quotidiana - teoria, métodos e estudos de caso. Imprensa de Ciências Sociais, Lisboa, 2002.

SÁ, C. P. Núcleo central das representações sociais. Petrópolis: Vozes. 2006.

SILVA, A. P. L. et. al. Prostituição e adolescência: prostituição juvenil no interior do Pará: "Trombetas e garimpos do Vale do Tapajós" - Belém - Pa. Centro de Defesa do Menor - CEJUP, 1997.

SOUSA, Filomena Sousa. O que é "ser adulto"? As práticas e representações sociais - A Sociologia do Adulto. VI Congresso Português de Sociologia - mundos sociais: saberes e práticas. Universidade Nova de Lisboa. Num. de série - 395. Jul/ 2008. Disponível em: http://www.aps.pt/vicongresso/pdfs/395.pdf. Acesso em Dez-2010. 2008.

SOUSA, Sônia M. Gomes. Pesquisas e estudos brasileiros sobre prostituição infantil e juvenil. Psicologia em Revista. Belo Horizonte, v. 8, n. 11, p. 11-31, jun. 2002. Acesso em 06 ago. 2008.

SOUZA, Jessé. A ralé brasileira: quem é e como vive. Belo Horizonte: Editora UFMG, 2009.

TAQUETE. Stella R. (Org.). Violência contra a mulher adolescente/jovem. Rio de Janeiro: EdUERJ - Editora da Universidade do Estado do Rio de Janeiro, 2007.

TAVARES, M. G. C. TRINDADE JUNIOR, S. C. (Org.). Cidades ribeirinhas na Amazônia: mudanças e permanências. Belém: ADUFPA, 2008.

TEIXEIRA, Lumena Celi. O Outro Lado do Espelho - a exploração sexual sob o olhar de adolescentes prostiuídas. Dissertação de Mestrado. PUC/SP, 2001.

TUPIASSU, Amarílis. Amazônia, das travessias lusitanas à literatura de até agora. Estud. av. [online]. vol.19, n.53, pp. 299-320. ISSN 0103-4014, 2005.

VIEIRA, A. S. Representações sociais de jovens-alunos de uma escola ribeirinha sobre exploração sexual juvenil nas balsas do Marajó e as implicações nas suas escolarizações. 2011. 163 f. Dissertação (Mestrado em Educação), Universidade Federal do Pará, Belém, 2011. 